\title{
Low- and High-Temperature Tolerance and Acclimation for Chlorenchyma versus Meristem of the Cultivated Cacti Nopalea cochenillifera, Opuntia robusta, and Selenicereus megalanthus
}

\author{
Brian R. Zutta, Park S. Nobel, Alenoush M. Aramians, and Arineh Sahaghian \\ Department of Ecology and Evolutionary Biology, University of California, Los Angeles, 621 Charles E. Young Drive South, \\ Los Angeles, CA 90095-1606, USA \\ Correspondence should be addressed to Brian R. Zutta, brian.zutta@gmail.com
}

Received 3 February 2011; Accepted 29 September 2011

Academic Editor: Kang Chong

Copyright (๑) 2011 Brian R. Zutta et al. This is an open access article distributed under the Creative Commons Attribution License, which permits unrestricted use, distribution, and reproduction in any medium, provided the original work is properly cited.

Dividing meristematic cells are thought to be more sensitive to extreme temperatures compared to other tissues, such as chlorenchyma. This was examined for low and high temperatures for three widely cultivated cacti: Nopalea cochenillifera, Opuntia robusta, and Selenicereus megalanthus. Temperature tolerances of chlorenchyma and meristem were based on the cellular uptake of the vital stain neutral red for plants at mean day/night air temperatures of $25 / 20^{\circ} \mathrm{C}$ and plants maintained at $10 / 5^{\circ} \mathrm{C}$ or $45 / 40^{\circ} \mathrm{C}$ to examine temperature acclimation. Meristematic cells tolerated $1.8^{\circ} \mathrm{C}$ lower low temperatures and $4.0^{\circ} \mathrm{C}$ higher high temperatures than chlorenchyma cells for the three species at $25 / 20^{\circ} \mathrm{C}$. Both tissue types showed acclimation, with a decrease or increase in temperature tolerated at $10 / 5^{\circ} \mathrm{C}$ or $45 / 40^{\circ} \mathrm{C}$, respectively. Meristematic cells were more tolerant of extreme temperatures compared to chlorenchyma, contrary to the prevailing belief, and may reflect an additional strategy for cacti to survive extreme temperatures.

\section{Introduction}

One of the most biologically important aspects of a plant's survival is its resistance to extreme low and high temperatures [1-3]. Indeed, a considerable investment of resources into different morphological and physiological strategies can occur to avoid damage resulting from extreme temperatures [4]. Freezing avoidance can be achieved by protecting plant organs through insulation and avoidance of ice nucleation [5]. An increase of inflorescence or stem pubescence with decreasing air temperature has been observed in arborescent rosette plants, such as in the genus Puya [4], and columnar cacti, such as Carnegiea gigantea [6,7]. Additionally, cactus stems often have lowered water content as winter approaches, which increases osmotic pressure and concomitantly lowtemperature tolerance $[1,8-10]$. Other cacti, such as Lemaireocereus thurberi [6] and Opuntia acanthocarpa [11], have increased stem shading by spines as shortwave irradiation increases, which moderates high stem temperatures [1].

Tissue sensitivity to extreme temperatures can determine survival, distribution, and areas of cultivation. In particular, sensitivity of chlorenchyma cells to extreme temperatures in cacti and other succulents has been widely studied with regard to plant distribution along elevational and latitudinal gradients and under different conditions for cultivation [1, $6,7,12]$. Plant tissue damage resulting from extreme temperature episodes may be fatal immediately or several years later [1]. Freezing can lead to the formation of intracellular ice crystals that can puncture the cell membrane and result in cell death [13]. Extracellular ice crystals can form from water diffusing out of the cells, resulting in cellular dehydration and disrupted metabolism [14]. High temperatures can denature proteins and disrupt membrane function [3].

Little research has been conducted on the different temperature sensitivities and acclimation among tissue types. On the other hand, different plant organs, such as fruits, roots, and stems, exhibit different sensitivities to extreme temperatures $[10,15]$. Also, considerable resources are allocated to anatomical features that protect vital vegetative areas, such as the apical meristem of many cacti [1]. Meristematic tissue is thought to be especially sensitive to extreme temperatures, as dividing cells are less resistant to cold temperatures $[16,17]$. Thus, it is hypothesized that chlorenchyma, parenchyma, 
and meristem tissue have different temperature tolerances and that such differences may be observed across cactus species.

In the present study, three species of Cactaceae were chosen that are increasingly cultivated and on which little physiological research has been conducted. Nopalea cochenillifera is treelike, can reach a height of $4 \mathrm{~m}$, and is native to southern Mexico; its cladodes (flattened stem segments) are used for food ("nopalitos") and fodder, and also to rear cochineal insects to obtain a commercially important red dye. Opuntia robusta is shrub- to tree-like, grows to a height of $3 \mathrm{~m}$, and is native to central Mexico; it is used for nopalitos and also as a source of fruits (called "tunas" or "cactus pears"). Selenicereus megalanthus is a hemiepiphytic vine cactus native to tropical America that is cultivated worldwide for its fruits (known as "yellow pitahayas"). This study measures differences of tolerance and acclimation to low and to high temperature among different tissue types, namely, chlorenchyma, parenchyma, and meristem.

\section{Materials and Methods}

2.1. Plant Material. Mature terminal cladodes of the platyopuntias Nopalea cochenillifera (L.) Salm-Dyck (also known as Opuntia cochenillifera (L.) P. Miller; [18]) and Opuntia robusta (L.) Salm-Dyck (both Cactaceae) were collected in October 2006 from the Agricultural Experiment Station, University of California, Riverside, where they had been maintained for eight years. Cladodes averaged $28 \mathrm{~cm}$ long for $N$. cochenillifera and $31 \mathrm{~cm}$ long for O. robusta. Mature stems $45 \mathrm{~cm}$ long of the hemiepiphyte Selenicereus megalanthus (Schumann ex Vaupel) Moran (also known as Hylocereus megalanthus (Schumann ex Vaupel) R. Bauer; [19] (Cactaceae) were obtained from the Cactus Trading Company (Jamul, CA, USA), in May 2000. All cacti were planted with one-quarter of their stem length in soil in individual plastic pots $20 \mathrm{~cm}$ in diameter that were filled to a depth of $18 \mathrm{~cm}$ with loamy sand [1]. The plants were maintained in a temperature-controlled glasshouse with mean day/night air temperatures of $25 / 20^{\circ} \mathrm{C}$ and were watered weekly with 5\% (0.05-strength) Hoagland's solution supplemented with micronutrients [20].

To examine temperature acclimation, plants were transferred in February 2007 to Conviron E-15 environmental chambers (Controlled Environments, Pembina, ND, USA), where five plants were maintained for 100 days with day/night air temperatures of $10 / 5^{\circ} \mathrm{C}$ or $45 / 40^{\circ} \mathrm{C}$ before determining the tissue temperature sensitivity.

2.2. Temperature Tolerances. The low- and the high-temperature sensitivities of chlorenchyma, parenchyma, and meristem cells were based on the uptake into the central vacuole of the vital stain neutral red, 3-amino7-dimethylamino-2-methylphenazine hydrochloride (Fisher Scientific, Hampton, NY, USA), which occurs only for living cells and indicates cellular membrane integrity $[15,21-$ 23]. In particular, this lipophilic dye readily penetrates the plasma membrane and the tonoplast of living plant cells when unprotonated; it becomes protonated and trapped in the central vacuole, which is acidic [24]. Tissue samples were taken with a cork borer $6 \mathrm{~mm}$ in diameter. To sample chlorenchyma and parenchyma cells, samples were taken at mid-stem, while meristem samples were taken at the areoles (axillary buds that produce a cluster of spine primordia). Copper-constantan thermocouples $0.51 \mathrm{~mm}$ in diameter were placed in contact with the samples to measure tissue temperature [10]; an HH-25TC digital thermometer (Omega Engineering, Stamford, CT, USA) was used to determine the thermocouple voltage. Samples were placed in $2-\mathrm{mL}$ plastic microcentrifuge tubes (low temperature) or in aluminium foil (high temperature) with moist filter paper to prevent desiccation and exposed to a particular treatment temperature for $60 \mathrm{~min}$, similar to the time that organs experience extreme temperatures in the field [1]. Low temperatures in $1-2^{\circ} \mathrm{C}$ steps decreasing from $4^{\circ} \mathrm{C}$ were obtained in an ULT- 80 ultra-low-temperature freezer (Rheem Manufacturing, West Columbia, SC, USA). High temperatures in $2-4^{\circ} \mathrm{C}$ steps increasing from $44^{\circ} \mathrm{C}$ were obtained in a STM135 mechanical convection oven (Precision Scientific, Winchester, VA, USA).

After treatment at a particular temperature, tissue slices approximately $200 \mu \mathrm{m}$ thick generally containing two cell layers were prepared with a razor blade. The slices were placed in $0.2 \%(\mathrm{w} / \mathrm{w})$ neutral red for chlorenchyma and parenchyma tissue and $0.1 \%$ for meristem tissue in $0.25 \mathrm{M}$ potassium phosphate buffer $(\mathrm{pH} 7.8)$ for $60 \mathrm{~min}$ at $25^{\circ} \mathrm{C}$ for stain uptake (stain concentrations for maximal uptake vary with tissue type; [21]). The slices were then washed in phosphate buffer for 10 min to remove excess stain, after which 300-350 cells were counted per plant at $100 \times$ using a $\mathrm{BH}-2$ phase-contrast light microscope (Olympus, Lake Success, NY, USA) to determine the percentages of stained (deep pink to red) and unstained (clear to light orange) cells. The low and the high temperatures that reduced the stain by $50 \%$ relative to the control at $25^{\circ} \mathrm{C}$, for which $90-94 \%$ of the cells took up the stain, was identified as the $\mathrm{LT}_{50}$, which reliably predicts cell death and eventual tissue necrosis $[1,10,15]$. Data are presented as means $\pm \operatorname{SE}(n=5$ plants $)$, and statistical significance was evaluated using Student's $t$ test (SPSS Science, Chicago, IL, USA).

\section{Results}

Uptake of the vital stain neutral red by chlorenchyma cells steadily decreased as the temperature was lowered below $0^{\circ} \mathrm{C}$ for all three species (Figure 1). For chlorenchyma cells of plants maintained at day/night air temperatures of $25 / 20^{\circ} \mathrm{C}$, the low temperature that halved the percentage of cells taking up neutral red compared to the control at $25^{\circ} \mathrm{C}$, $\mathrm{LT}_{50}$, was $-7.8 \pm 0.2^{\circ} \mathrm{C}$ for $N$. cochenillifera (Figure $1(\mathrm{a})$ ), $-7.5 \pm 0.2^{\circ} \mathrm{C}$ for O. robusta (Figure $1(\mathrm{~b})$ ), and $-5.8 \pm 0.2^{\circ} \mathrm{C}$ for $S$. megalanthus (Figure $1(\mathrm{c})$ ). Similar responses were found for parenchyma cells, with an average $\mathrm{LT}_{50}$ that was $0.3^{\circ} \mathrm{C}$ lower (n.s.). However, under the same conditions, meristem cells were more tolerant of freezing temperatures than chlorenchyma cells, as $\mathrm{LT}_{50}$ was $2.0^{\circ} \mathrm{C}$ lower $(P<0.01)$ for $N$. cochenillifera (Figure $1(\mathrm{a})), 2.6^{\circ} \mathrm{C}$ lower $(P<0.01)$ for 


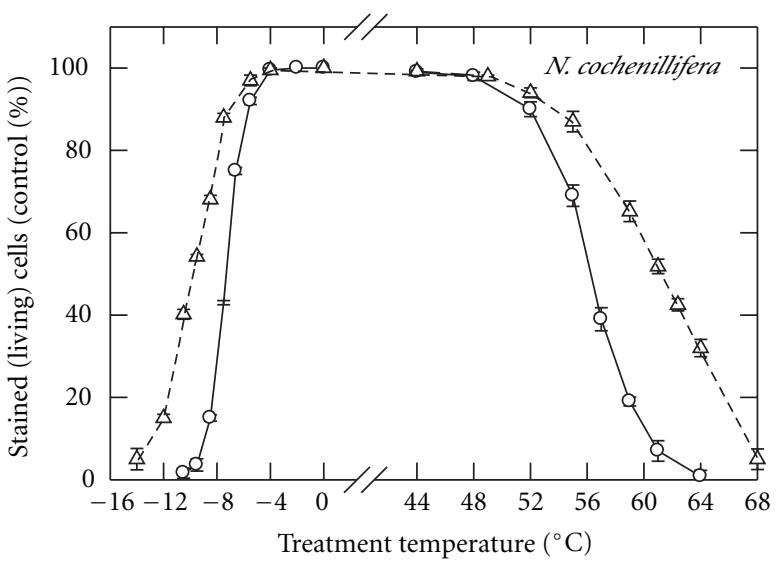

(a)

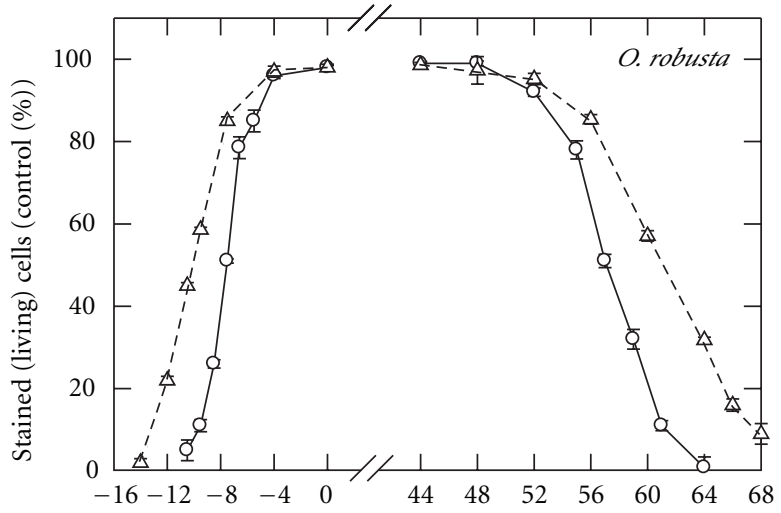

(b)

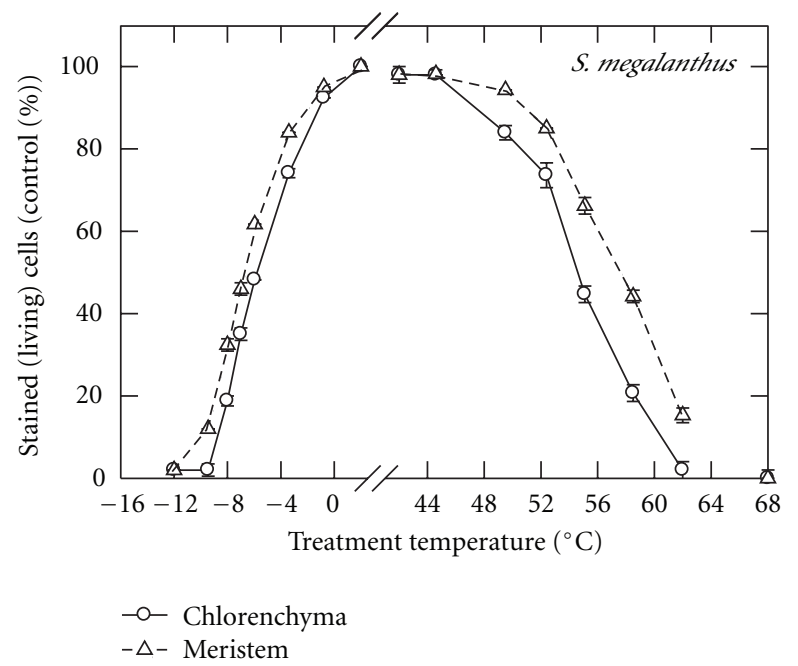

(c)

FIGURE 1: Cell sensitivity to extreme temperatures, as evidence by the uptake of the vital stain neutral red into the central vacuole, for stem chlorenchyma ( $($ ) and meristem $(\triangle$ ) cells of (a) Nopalea cochenillifera, (b) Opuntia robusta, and (c) Selenicereus megalanthus. Plants were maintained in the glasshouse with mean day/night air temperatures of $25 / 20^{\circ} \mathrm{C}$. Data are normalized relative to stain uptake at $25^{\circ} \mathrm{C}(90-94 \%$ of the cells) and are presented as means \pm SE $(n=5$ plants $)$.

O. robusta (Figure $1(\mathrm{~b})$ ), and $0.9^{\circ} \mathrm{C}$ lower $(P<0.05)$ for $S$. megalanthus (Figure 1(c)).

The increase of treatment temperature above $44^{\circ} \mathrm{C}$ also steadily decreased the uptake of neutral red by chlorenchyma cells for plants maintained at day/night air temperatures of $25 / 20^{\circ} \mathrm{C}$ (Figure 1). The high-temperature $\mathrm{LT}_{50}$ for chlorenchyma cells was $56.3 \pm 0.3^{\circ} \mathrm{C}$ for $N$. cochenillifera (Figure 1(a)), $57.1 \pm 0.2^{\circ} \mathrm{C}$ for O. robusta (Figure 1(b)), and $54.6 \pm 0.3^{\circ} \mathrm{C}$ for $S$. megalanthus (Figure $1(\mathrm{c})$ ). As for the low-temperature tolerance, parenchyma cells had a similar response as chlorenchyma cells, with an $\mathrm{LT}_{50}$ that averaged $0.4^{\circ} \mathrm{C}$ lower (n.s.). Meristem cells had a greater high-temperature tolerance than chlorenchyma cells, with $\mathrm{LT}_{50}$ being $5.0^{\circ} \mathrm{C}$ higher $(P<0.01)$ for $N$. cochenillifera (Figure $1(\mathrm{a})), 4.0^{\circ} \mathrm{C}$ higher $(P<0.01)$ for $O$. robusta (Figure $1(\mathrm{~b}))$, and $3.0^{\circ} \mathrm{C}$ higher $(P<0.01)$ for $S$. megalanthus (Figure 1(c)).

Acclimation to lower and higher temperatures occurred for all three species (Table 1). For plants maintained at
$10 / 5^{\circ} \mathrm{C}$ compared with $25 / 20^{\circ} \mathrm{C}$, the low-temperature $\mathrm{LT}_{50}$ for chlorenchyma cells was $1.3^{\circ} \mathrm{C}$ lower $(P<0.05)$ for $N$. cochenillifera, $1.3^{\circ} \mathrm{C}$ lower $(P<0.05)$ for $O$. robusta, and $0.7^{\circ} \mathrm{C}$ lower $(P<0.05)$ for $S$. megalanthus. Similarly, the low-temperature $\mathrm{LT}_{50}$ for meristem cells was lower by $1.5^{\circ} \mathrm{C}(P<0.05)$ for $N$. cochenillifera, $1.1^{\circ} \mathrm{C}(P<0.05)$ for O. robusta, and $0.7^{\circ} \mathrm{C}(P<0.05)$ for $S$. megalanthus maintained at $10 / 5^{\circ} \mathrm{C}$ compared with $25 / 20^{\circ} \mathrm{C}$ (Table 1 ). Thus, the low-temperature tolerated by both chlorenchyma and meristematic cells averaged $1.1^{\circ} \mathrm{C}$ lower when the air temperatures were decreased by $15^{\circ} \mathrm{C}$. For plants maintained at $45 / 40^{\circ} \mathrm{C}$ compared with $25 / 20^{\circ} \mathrm{C}$, the high-temperature $\mathrm{LT}_{50}$ for chlorenchyma cells was $5.2^{\circ} \mathrm{C}$ higher $(P<0.001)$ for $N$. cochenillifera, $5.5^{\circ} \mathrm{C}$ higher $(P<0.001)$ for $O$. robusta, and $4.1^{\circ} \mathrm{C}$ higher $(P<0.001)$ for $S$. megalanthus (Table 1). The high-temperature $\mathrm{LT}_{50}$ for meristem cells also showed acclimation, being $2.0^{\circ} \mathrm{C}$ higher $(P<0.05)$ for $N$. cochenillifera, $1.7^{\circ} \mathrm{C}$ higher $(P<0.05)$ for $O$. robusta, and $3.7^{\circ} \mathrm{C}$ higher $(P<0.05)$ for $S$. megalanthus at 
TABLE 1: $\mathrm{LT}_{50} \mathrm{~s}$ for chlorenchyma and meristem from stems of $N$. cochenillifera, O. robusta, and S. megalanthus maintained at day/night air temperatures of $10 / 5^{\circ} \mathrm{C}, 25 / 20^{\circ} \mathrm{C}$, or $45 / 40^{\circ} \mathrm{C}$. $\mathrm{LT}_{50}$ s for samples treated at low or high temperatures for 60 min were obtained graphically (Figure 1) relative to maximum stain uptake at $25^{\circ} \mathrm{C}$. Data are means $\pm \mathrm{SE}(n=5$ plants).

\begin{tabular}{|c|c|c|c|c|c|}
\hline \multirow{3}{*}{ Species } & \multirow{3}{*}{ Tissue type } & \multicolumn{4}{|c|}{$\mathrm{LT}_{50}\left({ }^{\circ} \mathrm{C}\right)$} \\
\hline & & \multicolumn{2}{|c|}{$\begin{array}{l}\text { Day/night air temperature for } \\
\text { low-temperature treatment }\end{array}$} & \multicolumn{2}{|c|}{$\begin{array}{l}\text { Day/night air temperature for } \\
\text { high-temperature treatment }\end{array}$} \\
\hline & & $10 / 5^{\circ} \mathrm{C}$ & $25 / 20^{\circ} \mathrm{C}$ & $25 / 20^{\circ} \mathrm{C}$ & $45 / 40^{\circ} \mathrm{C}$ \\
\hline \multirow{2}{*}{ N. cochenillifera } & Chlorenchyma & $-9.1 \pm 0.4$ & $-7.8 \pm 0.2$ & $56.3 \pm 0.3$ & $61.5 \pm 0.4$ \\
\hline & Meristem & $-11.3 \pm 0.4$ & $-9.8 \pm 0.3$ & $61.3 \pm 0.4$ & $63.3 \pm 0.2$ \\
\hline \multirow{2}{*}{ O. robusta } & Chlorenchyma & $-8.8 \pm 0.4$ & $-7.5 \pm 0.2$ & $57.1 \pm 0.2$ & $62.6 \pm 0.4$ \\
\hline & Meristem & $-11.2 \pm 0.4$ & $-10.1 \pm 0.3$ & $61.1 \pm 0.3$ & $62.8 \pm 0.2$ \\
\hline \multirow{2}{*}{ S. megalanthus } & Chlorenchyma & $-6.5 \pm 0.3$ & $-5.8 \pm 0.2$ & $54.6 \pm 0.3$ & $58.7 \pm 0.4$ \\
\hline & Meristem & $-7.4 \pm 0.4$ & $-6.7 \pm 0.3$ & $57.6 \pm 0.4$ & $61.3 \pm 0.4$ \\
\hline
\end{tabular}

$45 / 40^{\circ} \mathrm{C}$ compared with $25 / 20^{\circ} \mathrm{C}$ (Table 1 ). Thus, the hightemperature tolerance at $45 / 40^{\circ} \mathrm{C}$ compared with $25 / 20^{\circ} \mathrm{C}$ averaged $4.9^{\circ} \mathrm{C}$ higher for chlorenchyma cells and $2.5^{\circ} \mathrm{C}$ higher for meristematic cells.

\section{Discussion}

Tissue types varied in their tolerances of low and high temperatures for all three cactus species, as indicated by the temperature halving the uptake of a vital stain $\left(\mathrm{LT}_{50}\right)$. In particular, meristematic cells were the least sensitive to extreme temperatures following a $60 \mathrm{~min}$ exposure, with an average of $-10.0^{\circ} \mathrm{C}$ for low temperatures and $61.2^{\circ} \mathrm{C}$ for high temperatures for the two platyopuntia species, Nopalea cochenillifera and Opuntia robusta, under moderate growth conditions (day/night air temperatures of $25 / 20^{\circ} \mathrm{C}$ ). The chlorenchyma of these cacti had an average tolerance of $-7.7^{\circ} \mathrm{C}$ for low temperatures and $56.7^{\circ} \mathrm{C}$ for high temperatures. The hemiepiphytic cactus, Selenicereus megalanthus, was 2 to $4^{\circ} \mathrm{C}$ more sensitive to extreme temperatures under moderate growth conditions than the platyopuntias, but again the meristem was more tolerant than the chlorenchyma $\left(0.9^{\circ} \mathrm{C}\right.$ for low temperatures and $3.0^{\circ} \mathrm{C}$ for high temperatures). Overall, S. megalanthus was 1 to $3^{\circ} \mathrm{C}$ less sensitive to extreme temperatures than another highly cultivated hemiepiphytic cactus, Hylocereus undatus [25, 26]. The tolerances of extreme temperatures for parenchyma cells were similar to those of chlorenchyma cells.

The low-temperature acclimation of chlorenchyma and meristem cells averaged $1.3^{\circ} \mathrm{C}$ as day/night air temperatures were reduced by $15^{\circ} \mathrm{C}$ (from $25 / 20^{\circ} \mathrm{C}$ to $10 / 5^{\circ} \mathrm{C}$ ) for $N$. cochenillifera and $O$. robusta. Since plant death occurs about $4^{\circ} \mathrm{C}$ below the low-temperature $\operatorname{LT}_{50}[1,8,15]$, the chlorenchyma and mersitem of these cacti would not succumb until $-13^{\circ} \mathrm{C}$ and $-15^{\circ} \mathrm{C}$, respectively. The lower lowtemperature acclimation of $0.7^{\circ} \mathrm{C}$ for $\mathrm{S}$. megalanthus for both chlorenchyma and meristem reflects its greater sensitivity to cold temperatures than the two platyopuntias and was similar to the average cold hardening of 14 other species of cacti [1]. The high-temperature acclimation when day/night air temperatures were increased by $20^{\circ} \mathrm{C}$ (from $25 / 20^{\circ} \mathrm{C}$ to $45 / 40^{\circ} \mathrm{C}$ ) for $N$. cochenillifera and O. robusta chlorenchyma cells averaged $5.4^{\circ} \mathrm{C}$, comparable to 20 other species of cacti undergoing similar changes in air temperature $[1,11$, $15,25]$. The high-temperature acclimation of meristematic cells averaged $1.9^{\circ} \mathrm{C}$ for the two platyopuntia species; this smaller acclimation brought both tissue types to nearly the same average high-temperature tolerated $\left(64^{\circ} \mathrm{C}\right)$ by 18 other species of cacti [1]. The high-temperature acclimation of $S$. megalanthus for chlorenchyma and meristem cells averaged $3.9^{\circ} \mathrm{C}$, an acclimation greater than that of the more temperature-sensitive $H$. undatus [25].

The ability to acclimate or "harden" is an important ecological strategy that changes organ sensitivity to extreme temperatures in a matter of days [1, 15, 27]. Lowtemperature acclimation can involve cryoprotectants such as sugars $[5,28]$ and for cacti can be mediated by abscisic acid [29] or lower ice nucleation temperatures [9]. Acclimation to high temperatures often involves changes in membrane properties [30, 31] and can involve specific proteins [32].

The ecological significance of different low- and hightemperature tolerances for tissue types affects survival of cacti during extreme temperature events. In this regard, meristematic tissue averaged about $2.3^{\circ} \mathrm{C}$ more tolerant of low temperature then chlorenchyma for N. cochenillifera and O. robusta. Meristematic tissue of many cacti, particularly that of the apical meristem, is protected by various anatomical properties that increase minimum surface temperature [1]. The increased temperature tolerance of meristem tissue may be an additional freezing tolerance strategy to avoid lethal freezing injury. Similarly, meristematic tissue was $4.5^{\circ} \mathrm{C}$ more tolerant of high temperatures under moderate growth conditions compared to chlorenchyma. This physiological adaptation may again reflect a tendency of cacti to adopt multiple strategies to avoid high temperature damage, such as experienced by small seedlings [1]. For Opuntia bigelovii, detached stem segments can tolerate about $4^{\circ} \mathrm{C}$ higher temperatures after being on the ground for a week; larger diameter segments have a lower average maximum surface temperature, spines can raise stem segments off the ground and lower temperatures by up to $5^{\circ} \mathrm{C}$, and spines can additionally lower maximum stem temperatures by $3^{\circ} \mathrm{C}$ by shielding from shortwave irradiation $[1,6]$. Detached cladodes of $N$. cochenillifera and $O$. robusta may likewise 
avoid lethal high temperatures with their large diameters, temperature acclimation, and especially the meristematic tissue tolerance of high temperatures.

The enhanced low-temperature tolerance of meristematic tissue can also be an important factor limiting the distributional ranges of cacti, because avoidance of freezing temperatures by meristematic tissue assures the regrowth of shoots and roots after parts of the cacti have died. The northern limit of columnar cacti, such as the saguaro (Carnegiea gigantea), apparently is determined by the low temperatures occurring at the stem apex resulting in freezing damage $[6,7]$; for instance, they tend to grow on south-facing slopes in regions where freezing occasionally occurs, and seedlings must often establish under the canopy of nurse plants [1]. Morphological features, including stem massiveness, pubescence, and spines that cover apical meristem of some columnar and barrel cacti, afford special protection from freezing damage $[1,6,7]$. Potential regions for cultivation of other cacti are limited by minimum temperatures. The tropical hemiepiphyte $H$. undatas can only be cultivated in the $2 \%$ of California where extreme temperatures are above $-2.5^{\circ} \mathrm{C}$ and below $45^{\circ} \mathrm{C}$, compared to $36 \%$ for Opuntia ficusindica, primarily because the latter is only excluded from areas whose minimum temperature is below $-10^{\circ} \mathrm{C}$ [26].

In conclusion, the tolerance of chlorenchyma and parenchyma tissue of $N$. cochenillifera, O. robusta, and $S$. megalanthus to extreme temperatures was similar, whereas meristematic tissue was more tolerant of both low and high temperatures. This challenges the common perception that dividing cells are more sensitive to extreme temperatures compared to mature cells $[16,17]$. Chlorenchyma and meristem showed acclimation to extreme temperatures, with a larger acclimation to high temperatures for chlorenchyma. Multiple morphological and physiological strategies apparently allow cacti to survive extreme temperature, including those occurring during changing climatic conditions. The sensitivity and response of tissue types to extreme temperature, in particular meristematic tissue, may ultimately limit the latitudinal and the elevational natural distribution, as well as the regions of cultivation for various cacti and other species.

\section{Acknowledgments}

Financial support was provided by a Stephen A. Vavra Research Fellowship (to B. R. Zutta) and the UCLA Academic Senate Council on Research (to P. S. Nobel). The authors have no conflict of interests to declare and note that funders or suppliers of material had no role in the research design, data collection or analysis, decision to publish, or preparation of the paper.

\section{References}

[1] P. S. Nobel, Environmental Biology of Agaves and Cacti, Cambridge University Press, New York, NY, USA, 1988.

[2] A. C. Gibson, Structure-Function Relations of Warm Desert Plants, Springer, New York, NY, USA, 1996.
[3] A. H. Fitter and R. K. M. Hay, Environmental Physiology of Plants, Academic Press, San Diego, Calif, USA, 3rd edition, 2002.

[4] G. A. Miller, "Functional significance of inflorescence pubescence in tropical alpine species of Puya," in Tropical Alpine Environments: Plant form and Function, P. W. Rundel, A. P. Smith, and F. C. Meinzer, Eds., pp. 195-213, Cambridge University Press, Cambridge, UK, 1994.

[5] E. Beck, "Cold tolerance in tropical alpine plants," in Tropical Alpine Environments: Plant form and Function, P. W. Rundel, A. P. Smith, and F. C. Meinzer, Eds., pp. 77-110, Cambridge University Press, Cambridge, UK, 1994.

[6] P. S. Nobel, "Morphology, surface temperatures, and northern limits of columnar cacti in the Sonoran Desert," Ecology, vol. 61, pp. 1-7, 1980.

[7] P. S. Nobel, "Influences of minimum stem temperatures on ranges of cacti in southwestern United States and central Chile," Oecologia, vol. 47, no. 1, pp. 10-15, 1980.

[8] M. E. Loik and P. S. Nobel, "Freezing tolerance and water relations of Opuntia fragilis from Canada and the United States," Ecology, vol. 74, no. 6, pp. 1722-1732, 1993.

[9] G. Goldstein and P. S. Nobel, "Water relations and lowtemperature acclimation for cactus species varying in freezing tolerance," Plant Physiology, vol. 104, no. 2, pp. 675-681, 1994.

[10] P. S. Nobel and B. R. Zutta, "Temperature tolerances for stems and roots of two cultivated cacti, Nopalea cochenillifera and Opuntia robusta: acclimation, light, and drought," Journal of Arid Environments, vol. 72, no. 5, pp. 633-642, 2008.

[11] P. S. Nobel and E. G. Bobich, "Plant frequency, stem and root characteristics, and $\mathrm{CO}_{2}$ uptake for Opuntia acanthocarpa: elevational correlates in the northwestern Sonoran Desert," Oecologia, vol. 130, no. 2, pp. 165-172, 2002.

[12] P. S. Nobel and B. R. Zutta, "Rock associations, root depth, and temperature tolerances for the "rock live-forever," Dudleya saxosa, at three elevations in the north-western Sonoran Desert," Journal of Arid Environments, vol. 69, no. 1, pp. 15$28,2007$.

[13] L. Taiz and E. Zeiger, Plant Physiology, Sinauer Associates, Sunderland, Mass, USA, 4th edition, 2006.

[14] R. S. Pearce, "Plant freezing and damage," Annals of Botany, vol. 87, no. 4, pp. 417-424, 2001.

[15] P. S. Nobel and E. De La Barrera, "Tolerances and acclimation to low and high temperatures for cladodes, fruits and roots of a widely cultivated cactus, Opuntia ficus-indica," New Phytologist, vol. 157, no. 2, pp. 271-279, 2003.

[16] A. Sakai and W. Larcher, Frost Survival of Plants: Response and Adaptation to Freezing Stress, Ecological Studies, vol. 62, Springer, New York, NY, USA, 1987.

[17] E. H. Beck, R. Heim, and J. Hansen, "Plant resistance to cold stress: mechanisms and environmental signals triggering frost hardening and dehardening," Journal of Biosciences, vol. 29, no. 4, pp. 449-459, 2004.

[18] E. F. Anderson, The Cactus Family, Timber Press, Oregon, Ore, USA, 2001.

[19] N. Tel-Zur, S. Abbo, D. Bar-Zvi, and Y. Mizrahi, "Genetic relationships among Hylocereus and Selenicereus vine cacti (Cactaceae): evidence from hybridization and cytological studies," Annals of Botany, vol. 94, no. 4, pp. 527-534, 2004.

[20] E. Epstein and A. J. Bloom, Mineral Nutrition of Plants: Principles and Perspectives, Sinauer Associates, Sunderland, Massa, USA, 2nd edition, 2005.

[21] M. Guttenberger, "A rapid staining procedure for arbuscules of living arbuscular mycorrhizas using neutral red as acidotropic dye," Plant and Soil, vol. 226, no. 2, pp. 211-218, 2000. 
[22] I. C. Onwueme, "Rapid, plant-conserving estimate of heat tolerance in plants," Journal of Agricultural Science, vol. 92, pp. 527-536, 1979.

[23] D. Swain and D. N. De, "Vital staining - a technique for rapid screening of plant protoplast viability," Indian Journal of Experimental Biology, vol. 32, pp. 501-506, 1994.

[24] J. G. Dubrovsky, M. Guttenberger, A. Saralegui et al., "Neutral red as a probe for confocal laser scanning microscopy studies of plant roots," Annals of Botany, vol. 97, no. 6, pp. 1127-1138, 2006.

[25] P. S. Nobel and E. De la Barrera, "High temperatures and net $\mathrm{CO}_{2}$ uptake, growth, and stem damage for the hemiepiphytic cactus Hylocereus undatus," Biotropica, vol. 34, no. 2, pp. 225231, 2002.

[26] P. S. Nobel, E. De la Barrera, D. W. Beilman, J. H. Doherty, and B. R. Zutta, "Temperature limitations for cultivation of edible cacti in California," Madroño, pp. 228-236, 2002.

[27] M. Alberdi and L. J. Corcuera, "Cold acclimation in plants," Phytochemistry, vol. 30, pp. 3177-3184, 1991.

[28] P. S. Nobel, Wang Ning, R. A. Balsamo, M. E. Loik, and M. A. Hawke, "Low-temperature tolerance and acclimation of Opuntia spp. after injecting glucose or methylglucose," International Journal of Plant Sciences, vol. 156, no. 4, pp. 496-504, 1995.

[29] M. E. Loik and P. S. Nobel, "Exogenous abscisic acid mimics cold acclimation for cacti differing in freezing tolerance," Plant Physiology, vol. 103, no. 3, pp. 871-876, 1993.

[30] C. S. Pike and J. A. Berry, "Membrane phospholipid phase separation in plants adapted to or acclimated to different thermal regimes," Plant Physiology, vol. 66, pp. 238-241, 1980.

[31] A. Srinivasan, H. Takeda, and T. Senboku, "Heat tolerance in food legumes as evaluated by cell membrane thermostability and chlorophyll fluorescence techniques," Euphytica, vol. 88, no. 1, pp. 35-45, 1996.

[32] A. Wahid, S. Gelani, M. Ashraf, and M. R. Foolad, "Heat tolerance in plants: an overview," Environmental and Experimental Botany, vol. 61, no. 3, pp. 199-223, 2007. 

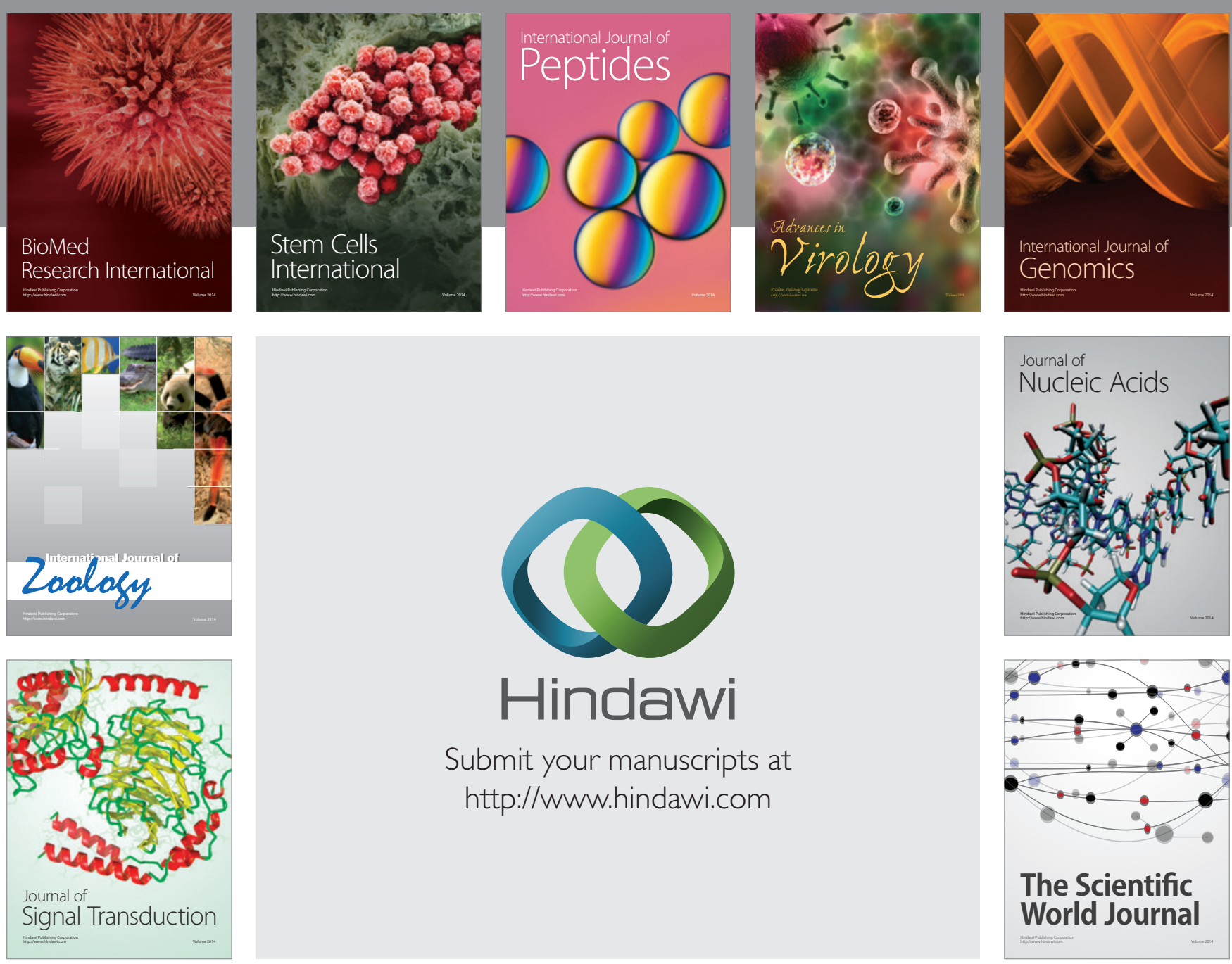

Submit your manuscripts at

http://www.hindawi.com
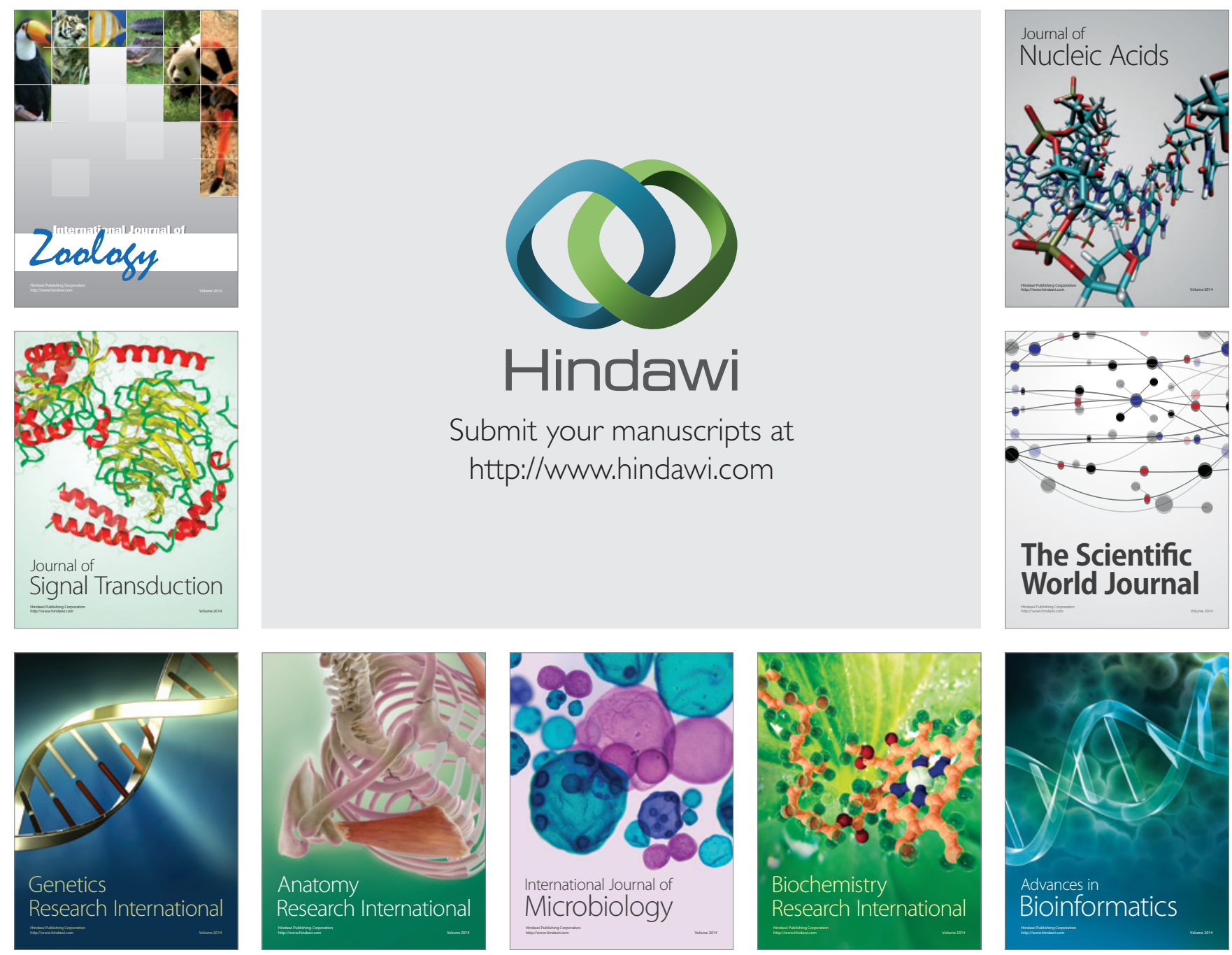

The Scientific World Journal
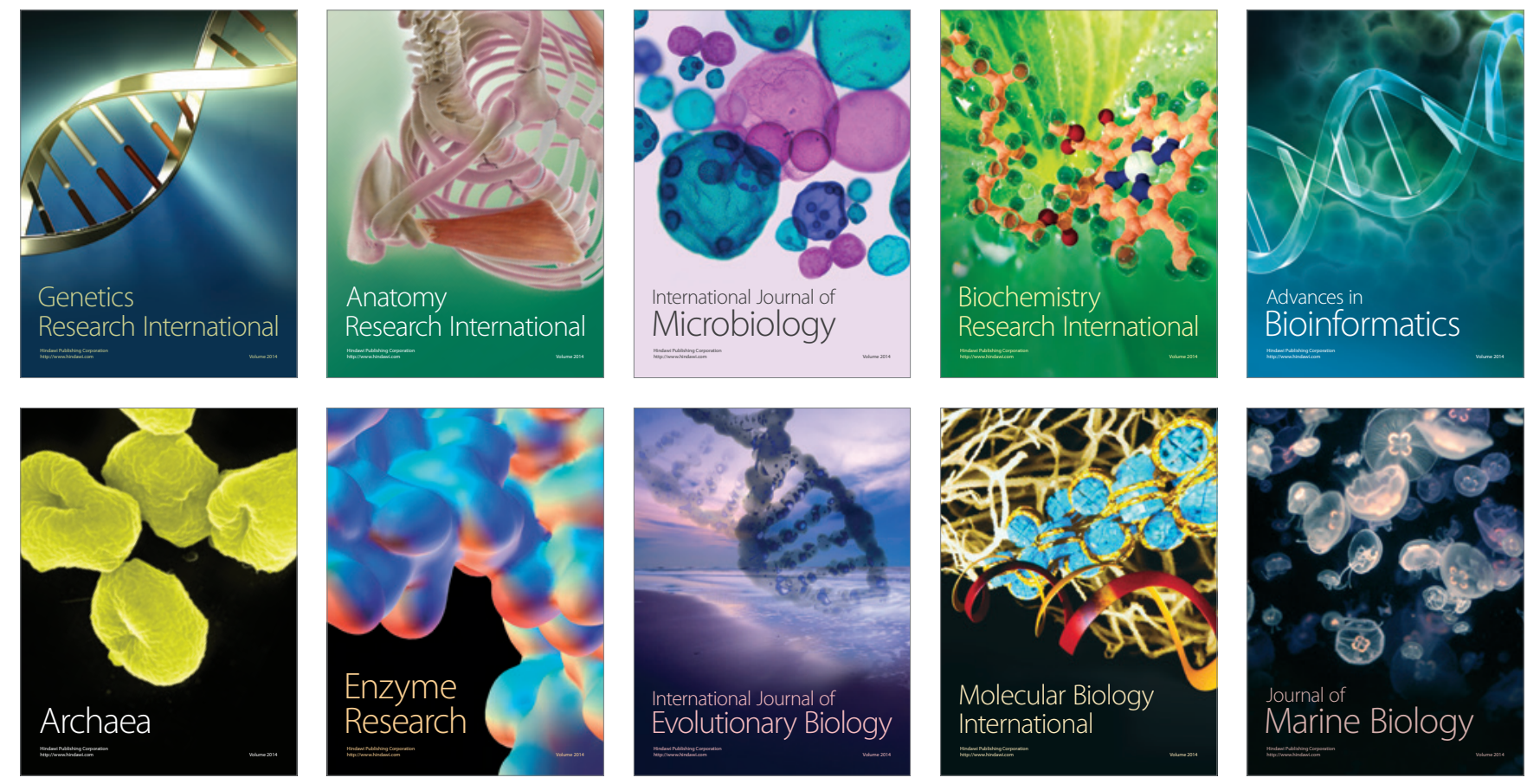